\title{
FORMAÇÃO DE PROFESSORES PARA O ENSINO DE PORTUGUÊS COMO SEGUNDA LÍNGUA PARA SURDOS: IMAGENS DE SI, DO SURDO E DO PROCESSO DE FORMAÇÃO
}

\author{
FORMACIÓN DE PROFESORES PARA LA ENSEÑANZA DE ESPAÑOL COMO SEGUNDA \\ LENGUA PARA SORDOS: IMÁGENES DE SÍ, DEL SORDO Y DEL PROCESO DE FORMACIÓN
}

TEACHER TRAINING FOR THE TEACHING OF PORTUGUESE AS A SECOND LANGUAGE FOR THE DEAF: SELF-IMAGES, THE DEAF AND THE FORMATION PROCESS

Luciana Cardoso Araújo Instituto Federal do Norte de Minas Gerais (IFNMG)

Maria Clara Maciel de Araújo Ribeiro* Universidade Estadual de Montes Claros (Unimontes)

\begin{abstract}
RESUMO: Este trabalho objetiva investigar a formação de professores para o ensino de português para surdos em escolas inclusivas a partir da perspectiva dos próprios professores. Trata-se de um estudo qualitativo que ofereceu um curso de formação continuada a professores de português e analisou o discurso do professor-cursista antes, durante e após a referida formação, com vistas a mapear a construção de imagens de si, dos surdos e do curso, bem como as ressonâncias dessa formação na prática pedagógica. Para a análise dos dados, recorremos à Análise do Discurso de orientação francesa, sobretudo à categoria de ethos discursivo. Os resultados demonstram que os professores-cursistas vão, ao longo do curso, (des)construindo imagens de si, do curso e da própria formação, refletindo sobre a própria prática e empoderando-se, sem, contudo, oferecer percepções claras sobre a contribuição efetiva dessa formação para a prática, dada a complexidade da inclusão de surdos no Brasil. PALAVRAS-CHAVE: Surdos. Ensino de português. Formação de professores.
\end{abstract}

\footnotetext{
Mestre em Letras pela Universidade Estadual de Montes Claros. Pedagoga do IFNMG. E-mail: proflucardoso@gmail.com.

Doutora em Estudos Linguísticos pela Universidade Estadual de Minas Gerais. Professora do Programa de Mestrado Profissionalem Letras da Universidade Estadualde MontesClaros. E-mail: mclaramaciel@hotmail.com.
} 
RESUMEN: Este trabajo tiene como objetivo investigar la formación de profesores para la enseñanza de portugués para sordos en escuelas inclusivas desde la perspectiva de los propios profesores. Se trata de un estudio cualitativo que ofreció un curso de formación continuada a profesores de portugués y analizó el discurso del profesor antes, durante y después de dicha formación, con miras a mapear la construcción de imágenes de sí y de los sordos, así como las resonancias de esa formación en la práctica. Para el análisis, recurrimos al Análisis del Discurso de orientación francesa. Los resultados demuestran que los profesores-cursistas van, a lo largo del curso, (des) construyendo imágenes de sí, de los sordos y de la propia formación, reflexionando sobre la propia práctica y empoderándose, sin embargo, sin ofrecer percepciones claras sobre la contribución efectiva de esa formación para la práctica, dada la complejidad de la inclusión de sordos en Brasil.

PALABRAS CLAVE: Sordos. Enseñanza de Portugués. Formación de profesores.

ABSTRACT: This work aims to investigate the teacher training of Portuguese as a second language for the deaf in inclusive schools from the perspective of the involved teachers. This qualitative study offered a continuous Portuguese teacher's training course and analyzed the teacher's discourse before, during and after this course. It aimed to map the image construction of themselves, of the deaf and of the course as well as the resonance of this training in their pedagogical practice. In order to analyze the data, French Discourse Analysis has been used, especially the category of discursive ethos. The results demonstrate along the course, the trained teachers (de)construct their self-images, the images surrounding the course and their own formation, reflecting on their own professional practice and empowering themselves, though without offering clear perceptions on the effective contribution of this formation for their practice, given the complexity of the inclusion of deaf students in Brazil.

KEYWORDS: Deaf. Portuguese teaching. Teacher formation.

\section{INTRODUÇÃO}

Inúmeras pesquisas têm revelado que grande parte dos problemas que os surdos enfrentam na apropriação do português escrito deriva de insuficiências dos contextos educacionais, não de limitações dos sujeitos (FERNANDES, 2003; SKLIAR, 1999; SOUZA, GÓES, 1999; QUADROS, 2005; RIBEIRO, 2013). Entre as insuficiências, consta-se a configuração precária das escolas inclusivas para atenderem às necessidades dos sujeitos que recebem. Tal precariedade costuma ser ilustrada sobretudo por insuficiências na formação do professor e pela falta, para os surdos, de oportunidades de apropriação e vivência da Libras no ambiente escolar, entre outras questões.

A formação do professor de Português é considerada ponto nevrálgico da educação de surdos, pois, sem conhecer princípios da Libras, da educação bilíngue para surdos e estratégias de ensino de segunda língua de segunda modalidade, não é possível desenvolver um trabalho relevante com surdos ${ }^{1}$.

A partir disso, na arena discursivo-social, observam-se discursos polêmicos sobre a formação de professores para o ensino de português para surdos em escolas inclusivas: ora a consideram como "salvadora" dos processos educativos que envolvem surdos, ora a consideram como um efeito placebo, dado os problemas decorrentes da configuração político-educacional da inclusão no Brasil, que impedem processos relevantes. Perguntamo-nos, contudo, pelas visões dos próprios professores envolvidos nesse processo.

Assim, neste estudo, selecionamos um feixe do tema da formação de professores de Português para surdos com vistas a responder à seguinte questão norteadora: na perspectiva do professor de Português, em que medida a sua formação melhora os processos de ensino-aprendizagem que envolvem surdos na escola inclusiva? Quais são as imagens que os professores constroem de si, dos surdos e do próprio evento de formação antes, durante e após o seu término?

\footnotetext{
${ }^{1}$ Justificamos que a Libras é a força motriz possibilitadora de todo processo ensino-aprendizagem que envolva surdos. Ela tem sido apontada como suporte da cognição, veículo da cultura e fundamentadora da identidade (RIBEIRO, 2013). Além disso, há indícios de que, quanto mais Libras se sabe, mais português se pode vir a saber, pois parece haver uma relação de transferência de habilidade linguística mesmo entre línguas de modalidades diferentes.
} 
Tal discussão se torna pertinente quando se percebe que, na escola inclusiva, muitas vezes, o professor de Português é visto como um agente educacional superlativo, capaz de contornar agruras socioeducacionais derivadas de décadas de políticas questionáveis e de investimentos insignificantes, ou como um profissional que, devido a características do sistema, pouco pode, de fato, contribuir para a formação de surdos. Discutimos neste estudo, pois, as contribuições e os limites da formação de professores para o ensino de português para surdos nas escolas inclusivas, a partir da perspectiva dos próprios sujeitos envolvidos.

Para abordar essas questões, focalizamos o discurso do professor de Português antes, durante e após um curso de formação continuada, oferecido na modalidade $\mathrm{EaD}$, com duração de noventa horas. Para a análise dos dados, recorremos à Análise do Discurso de orientação francesa, especialmente às categorias ethos discursivo (MAINGUENEAU, 2014) e jogos de imagem (PÊCHEUX, 1988). Assim, analisamos o discurso desses professores antes, durante e após a referida formação, com vistas a mapear o que melhora, via formação, e o que exatamente não pode ser modificado apenas por ela, na visão dos professores.

A seguir, discutimos aspectos da formação de professores e descrevemos, na sequência, os procedimentos da pesquisa. Por fim, a análise dos dados será apresentada e as conclusões estabelecidas.

\section{POLÍTICAS PÚBLICAS DE FORMAÇÃO DE PROFESSORES}

Desde a intensificação da reforma educacional brasileira na década de 1990, especialmente com a promulgação da terceira LDB Lei de Diretrizes e Bases da Educação Nacional (BRASIL,1996) -, a temática da formação de professores tornou-se relevante e frequente, tanto em trabalhos acadêmicos quanto em leis e decretos. No interior dessas discussões, a formação precária é contextualizada como mais um entrave à melhoria da qualidade da educação brasileira.

No discurso oficial, percebe-se uma relação direta entre a melhoria da qualidade da educação e a formação de professores, independente do nível de ensino, o que pode ser observado nos Referenciais para a Formação de Professores, emitidos pelo Ministério da Educação em 1998:

Não se trata de responsabilizar pessoalmente os professores pela insuficiência das aprendizagens dos alunos, mas de considerar que muitas evidências vêm revelando que a formação de que dispõem não tem sido suficiente para garantir o desenvolvimento de capacidades imprescindíveis para que crianças e jovens não só conquistem sucesso escolar, mas, principalmente, capacidade pessoal que lhes permita plena participação social num mundo cada vez mais exigente sob todos os aspectos. (BRASIL, 1998, p. 26)

Nessa ótica, apesar de tentar dizer o contrário, o discurso oficial desconsidera os variados e complexos fatores que determinam a baixa qualidade do ensino e atribui à formação limitada dos professores a responsabilidade pelo fracasso do aluno e, por conseguinte, da escola. Em outros termos, esse discurso destaca a importância do papel do professor para a formação holística do indivíduo, apontando o despreparo dos professores como uma das causas mais importantes do insucesso escolar.

Nessa perspectiva, desde a década de 1990, com a intensificação das Reformas da Educação², o Estado estabelece políticas de formação de professores e, segundo Gatti (2008), a partir dos anos 2000, crescem significativamente as iniciativas referentes à formação continuada, que abrigam desde cursos de extensão de natureza bem diversificada até cursos de formação que outorgam diplomas profissionais, seja em nível médio, seja em nível superior. Segundo a autora, torna-se “[...] difícil obter um número exato das iniciativas colocadas nessa rubrica, porque provêm de inúmeros setores dentro do sistema público, estadual, municipal ou federal" (GATTI, 2008, p. 56). Contudo, essa mesma autora entende que essas iniciativas são, na verdade, de suprimento a uma formação inicial precária, especialmente na esfera pública.

\footnotetext{
${ }^{2}$ No início da década de 1990, a Unesco, com financiamento e assessoria do Banco Mundial, organizou reuniões mundiais que desencadearam um processo de reformas educacionais na América Latina e no Brasil. As orientações para a implantação dessas reformas se fizeram através de documentos como a Declaração mundial sobre educação para todos, de Jomtien (UNESCO, 1990).
} 
Talvez em função das novas exigências do mundo do trabalho e das inovações e facilidades trazidas pelas tecnologias digitais, a ideia da atualização constante vem sendo divulgada e tem mobilizado boa parte dos profissionais da educação, todavia, há uma distância muito grande entre o que propõem as políticas de formação, especialmente no que se refere à Educação Inclusiva, e como as coisas realmente acontecem na escola. Na maioria das vezes, trata-se de ações fragmentadas, desvinculadas da realidade educacional e dos desafios práticos encontrados pela escola.

A despeito da formação de professores para o ensino de português para surdos na escola inclusiva, percebem-se, de modo geral, políticas públicas de formação aligeiradas, limitadas e descontínuas, perpetuando a carência de docentes qualificados, que atendam às especificidades dessa política educacional, contrariando a Lei de Diretrizes e Bases da Educação Nacional, que em seu Artigo 59 estabelece que os sistemas de ensino assegurarão aos educandos com necessidades especiais, dentre outras coisas, "III - professores com especialização adequada em nível médio ou superior, para atendimento especializado, bem como professores do ensino regular capacitados para a integração desses educandos nas classes comuns”(BRASIL, 1996, p.21).

Além disso, no caso das pessoas surdas, especificamente no Decreto no 5626 (BRASIL, 2005), o poder público se compromete, ainda, entre outras coisas, a promover cursos de formação de professores para o ensino da Língua Portuguesa como L2 para pessoas surdas, e a prover as escolas com professores regentes de classe com conhecimento acerca da singularidade linguística dos surdos e professores para o ensino de Língua Portuguesa como L2 para surdos (BRASIL, 2005). Todavia, o que se percebe até agora são cursos de formação inicial com carga horária irrisória destinada à disciplina Libras, e alguns cursos esporádicos de formação continuada em Libras, com carga horária reduzida. A esse respeito, Lorenzetti (2006, p. 61) conclui sua pesquisa afirmando que:

Os resultados evidenciam a necessidade de dar continuidade ao processo de formação dos professores que atuam com alunos surdos, pois um dos aspectos relevantes da pesquisa refere-se à forma de comunicação utilizada pelos alunos surdos, sendo que a comunicação através da Língua de Sinais e não da linguagem oral, demonstrou ser o maior obstáculo que dificulta o processo de inclusão.

A respeito da formação de professores, Rodrigues (2006) defende a ideia de que o desenvolvimento de competências para a Educação Inclusiva, ainda que possa ter uma fase de sensibilização na formação inicial, só poderá ser plenamente assumido ao longo de uma prática em serviço, que deve ser permeada continuamente por reflexão e mudanças. Nesse sentido, a Declaração de Salamanca (1994) faz um apelo aos governantes para assegurar que os programas de formação do professorado, tanto inicial como continuada, estejam voltados para atender às necessidades educacionais nas escolas.

Contudo, convém ressaltar que formar o professor para atuar na Educação Inclusiva é prepará-lo para um outro modo de educar. A formação para este setor deve ser entendida como uma construção contínua de saberes e aptidões. Precisa envolver reflexão e questionamento constante sobre a própria prática, buscando sua ressignificação e reconstrução, tendo em vista os preceitos da inclusão e do respeito às diferenças.

Skliar (1997, p.7) ressalta a dimensão política dessa formação, compreendida como relação de poder e conhecimento que deve estar contemplada, não só na proposta pedagógica, mas além dela. $\mathrm{O}$ autor propõe a ruptura do modelo vigente, caracterizado "[...] como positivista, ahistórico e despolitizado", e defende uma ressignificação da escola como espaço de fronteira, onde diferentes identidades possam conviver.

Contudo, em relação ao ensino de português para surdos em escolas inclusivas, apesar de prever grandes contribuições advindas da formação desse professor, acreditamos também que a formação docente por si só não seja suficiente para garantir uma prática verdadeiramente inclusiva, pautada na educação bilíngue, pois são diversos os fatores que dificultam a inclusão da comunidade surda no espaço escolar brasileiro. Fatores esses que vão desde a discriminação do surdo e a não aceitação da Libras como sua língua materna, a demora na contratação de intérprete e a inadequação das estratégias linguísticas e metodológicas direcionadas aos surdos, até as diferenças curriculares e a dificuldade para se trabalhar Língua Portuguesa em classes mistas - com alunos surdos e ouvintes - e superlotadas, utilizando metodologias diferenciadas.

Araújo \& Ribeiro | Formação de professores para o ensino de português como segunda língua para surdos.. 
Apesar disso, é preciso defender a imensa contribuição da formação continuada nesse contexto; se ela não pode tudo, certamente pode muito, e é exatamente essa a questão que se buscou na pesquisa: delinear as contribuições e os limites da formação de professores para o ensino de português como L2 em escolas inclusivas (ARAÚJO, 2015).

\section{DESCRIÇÃO DOS PROCEDIMENTOS}

A presente pesquisa foi desenvolvida por meio de um estudo qualitativo, de natureza interpretativa, que propôs a elaboração e o desenvolvimento de um curso de formação de professores para o ensino de português como segunda língua para surdos, na modalidade Educação a Distância $(\mathrm{EaD})$, buscando responder aos questionamentos elencados anteriormente.

A escolha da modalidade a distância justifica-se pelo fato de muitos professores trabalharem em dois e, às vezes, em três turnos diários, resultando na indisponibilidade de tempo e de motivação para frequentar cursos presenciais, fato que inviabilizaria a capacitação desses profissionais. Além disso, a EaD tem como benefícios a flexibilidade, a comodidade, o baixo custo, a interatividade, o incentivo à aprendizagem colaborativa e ao desenvolvimento da autonomia do cursista - fatores importantes quando se pensa em formação continuada.

O curso contou com uma carga horária de noventa horas e duração de três meses ${ }^{3}$. Dele participaram (trinta professores de Língua Portuguesa do segundo ciclo do Ensino Fundamental da rede pública de ensino, tendo prioridade aqueles que tinham ou tiveram alunos surdos em suas classes.

O curso, composto por bases político-cultural, linguística e pedagógica, contou com as seguintes disciplinas: a) Definição políticocultural dos surdos na pós-modernidade; b) Teorias de aquisição linguística: Libras e português; c) Prática de ensino a alunos surdos e d) Interpretação e educação: a parceria com o profissional intérprete.

Para a realização da pesquisa, aplicou-se um questionário a todos que compareceram ao encontro presencial do Curso de Formação de Professores para o Ensino de português como Segunda Língua para Surdos ${ }^{4}$. Em seguida, tendo em vista o perfil dos participantes, fez-se, durante a realização do curso em questão, o acompanhamento sistemático de três cursistas, via Plataforma Moodle, visando observar, por meio da análise interpretativa de fóruns e outras formas de participação no curso, as modulações imagéticas que os professores em processo de formação continuada constroem de si (o ethos discursivo desses professores-cursistas), assim como as imagens que produzem sobre os surdos e o próprio processo de formação ao qual se submeteram, buscando captar, especialmente, possíveis transformações ou manutenções de posicionamentos durante a realização do curso. Ao término do curso, passados cerca de quarenta dias, os concluintes responderam a outro questionário. Portanto, o corpus do presente estudo é composto por dois questionários, discussões e atividades realizadas pelos três cursistas selecionados.

\subsection{PERSPECTIVA TEÓRICA E CATEGORIAS DE ANÁLISE}

Neste trabalho, analisamos as modulações imagéticas que os professores em processo de formação continuada revelam de si (ethos discursivo), no interior do seu discurso, assim como as imagens que produziram sobre os surdos e sobre o próprio processo de formação ao qual se submeteram, buscando captar possíveis transformações em seu posicionamento ao longo do curso ofertado. Para tanto, partimos da Análise do Discurso (AD) de orientação francesa, privilegiando as noções de ethos discursivo, apresentada

\footnotetext{
${ }^{3} \mathrm{O}$ curso foi ofertado pelo Instituto Federal de Educação, Ciência e Tecnologia do Norte de Minas Gerais - IFNMG - Campus Montes Claros, com o apoio da Diretoria de Educação a Distância do mesmo Instituto, e em parceria com outras instituições de ensino, que cederam profissionais qualificados para ministrarem as disciplinas do curso, a saber: o IFNMG - Campus Januária, o IFSP-Campus Salto e a Universidade Estadual de Montes Claros.

${ }^{4}$ O encontro presencial do curso ocorreu no dia 23 de agosto de 2014, no Instituto Federal de Educação, Ciência e Tecnologia do Norte de Minas Gerais (IFNMG)

- Campus Montes Claros, e será melhor apresentado no decorrer deste trabalho.
} 
por Maingueneau (2014), e a noção de jogos de imagem, de Pêcheux (1988), perspectiva e conceitos que passamos a discutir brevemente.

Entre várias definições possíveis, Possenti (2009, p. 9) define a AD como "[...] um conjunto de teorias sobre as restrições que um discurso sofre em sua constituição”. Nessa perspectiva, assume-se que a circulação, o gênero e a interpretação de dado discurso não são livres, mas condicionados a uma série de fatores sociais. Isso significa dizer que um discurso "não circula em qualquer lugar", "não toma livremente uma fórmula genérica qualquer", "não é interpretado de qualquer maneira por qualquer um". A produção de discursos é, portanto, de alguma forma, controlada em nossa sociedade, seja pela formação discursiva, seja pelas imagens que buscamos construir ou pelas intencionalidades.

Possenti (2009) informa que pelo menos duas vertentes importantes coexistem na AD. A primeira investiga o dispositivo social de circulação de textos, sem foco específico na questão dos sentidos, priorizando reflexões sobre os sistemas de controle discursivos exercidos pela sociedade. A segunda, com foco específico na produção de sentidos, embora também reflita sobre questões de controle na ordem do discurso, prioriza os modos de significação, os implícitos, as opacidades etc. Cada uma a seu modo, as duas vertentes interessam-se por estudar formas de restrições a que os discursos se submetem e a partir dos quais se moldam, seja na perspectiva da circulação ou da produção de sentidos.

Neste estudo, a segunda vertente ganha proeminência, pois nos interessa compreender os fios discursivos utilizados pelos sujeitos da pesquisa ao falarem de si, dos surdos e da formação. É inegável que, embora situado na segunda vertente, este estudo mantenha estreita relação com a primeira, uma vez que tratar de imagens é tratar, de alguma maneira, de restrições. Assim, como dito, partiremos das noções de ethos discursivo para abordar a imagem de si projetadas pelos cursistas e da noção de jogo de imagens, para tratar das imagens produzidas sobre os surdos e sobre a formação.

O jogo de imagem é entendido por Ribeiro (2008, p. 96) como “[...] efeito de sentidos entre A e B, que são lugares determinados na estrutura de uma formação social, lugares esses que estão representados por uma série de formações imaginárias”: a imagem que o falante projeta de si (que se relaciona à projeção do ethos discursivo de Maingueneau), as imagens que tem daquele/daquilo de que $(\mathrm{m})$ fala, as imagens que tem daquele com quem fala etc. Neste trabalho, buscaremos perceber a projeção dessas duas primeiras imagens, refletidas no texto, ou seja, a imagem que o falante tem de si e as imagens que tem daquele (surdo) ou daquilo (formação de professores) de que $(\mathrm{m})$ fala, refletindo por meio desse jogo de imagens sobre o valor da formação para os sujeitos envolvidos.

À medida que o sujeito ocupa uma determinada posição social, constrói um jogo de imagens de si e do outro que se projeta em seu discurso: imagens do lugar que ocupa, do lugar que ocupa seu interlocutor e do próprio discurso. Assim, o sujeito do discurso ocupa um lugar social e a partir dele enuncia, estando submetido às normas da formação discursiva na qual está inserido, não sendo, portanto, livre para dizer o que quer (PÊCHEUX, 1988). Isso significa dizer que, embora os discursos sejam, em alguma medida, manifestações do indivíduo, eles são predominantemente marcas do coletivo, pois se inscrevem, invariavelmente, numa comunidade discursiva específica. Assim, falamos sempre de uma posição social enquanto professores, pais, filhos, pesquisadores etc.

Esse jogo de imagens revela uma rede imaginária subjacente que também determina a produção discursiva, intervindo nas suas condições de produção (RIBEIRO, 2008). Dessa forma, as diferentes posições do sujeito determinam as imagens que são construídas dele ou por ele, proposta posteriormente examinada por Maingueneau, na proposição da categoria ethos discursivo.

Segundo Maingueneau (2014), Aristóteles, em postulados da Retórica Antiga, foi o primeiro a pensar nas imagens de si construídas pelo locutor em seu momento de fala. O ethos aristotélico consiste, assim, em causar uma impressão de confiabilidade, em emitir uma imagem de si capaz de convencer e transmitir confiança através da construção do discurso. Diante disso, o ethos é entendido neste trabalho como a imagem de si que o enunciador constrói no e pelo discurso, por sua maneira de dizer e pelas escolhas linguísticas que faz, já que é construído na enunciação e por ela (MAINGUENEAU, 2008). 
Tendo em vista a extensão das discussões, e evitando tornar a análise de dados muito exaustiva, optou-se por fazer recortes representativos dos discursos estabelecidos pelos cursistas selecionados para a pesquisa, estando cientes da subjetividade que permeia toda e qualquer pesquisa, como pontua Fiorin (1988). Concordamos com esse autor quando afirma que, em uma investigação, não estudamos os fenômenos em si, ou seja, o que efetivamente ocorre no mundo; estudamos dados previamente circunscritos e determinados por uma determinada assunção teórica e metodológica.

Dessa maneira, apresentaremos abaixo uma das possíveis análises dos dados coletados nesta pesquisa, conduzindo-a para que se perceba: i) a(s) imagem(ns) que o cursista constrói de si (ethos) antes, durante e após o curso; ii) a(s) imagem(ns) que apresenta do surdo antes, durante e após o curso; iii) as imagens do próprio processo de formação continuada a que se submeteu, buscando vislumbrar os principais aspectos defendidos e combatidos em seu discurso.

Por meio dessas categorias, será possível flagrar o professor em seu processo de formação e transformação, focalizando o que projeta de si, do surdo e da própria formação, de modo a pensar, ao fim, nos limites e contribuições da formação.

\section{ANÁLISES E RESULTADOS}

A análise dos dados coletados ${ }^{5}$ indicam que, no início do curso, os professores-cursistas apresentaram imagens negativas de si (ressaltando o despreparo, a angústia e a incapacidade de ensinar a um aluno surdo), ao mesmo tempo em que projetaram uma imagem de docente disposto a aprender mais e a melhorar sua prática, veiculando imagens positivas sobre a formação de professores, como se percebe nos seguintes fragmentos em que os sujeitos respondem sobre a experiência de se ensinar português a alunos surdos: Infelizmente, creio que não consegui ensinar o conteúdo, era imatura e incapacitada para esta situação, por sorte logo o aluno mudou para cidade, transferindo de escola (S14) ; Sempre tive grande sensação de impotência por não saber como ensiná-los a Lingua Portuguesa como L2"(S5); Estou acreditando neste curso para dar conta de melhorar o ensino de português aos meus alunos surdos (S11); Sim, formação continuada em português para surdos abrirá horizontes para o professor e os alunos surdos, pois aprendendo o professor atenderá melhor os anseios de seus alunos surdos (S19).

Seus discursos deixaram transparecer a imagem do aluno surdo como ser defeituoso, limitado e pouco ágil, como é possível notar nos trechos a seguir: Há sempre um desafio a ser superado e cada surdo possui suas particularidades, mais fluentes, menos fluentes, ou outras limitaçães (S1); "Ao longo do ano letivo, são poucos os momentos de interação professor-aluno, causada pelo meu despreparo, pela responsabilidade com os outros alunos que são ágeis (S6).

Dessa maneira, as imagens construídas antes do curso podem ser assim sintetizadas:

\begin{tabular}{c|c|c} 
Imagem de si (ethos) & Imagem do surdo & Imagem da formação de professores \\
\hline $\begin{array}{c}\text { Angustiado, incapacitado, despreparado } \\
\text { para lidar com o aluno surdo; ao mesmo } \\
\text { tempo inquieto, disposto a aprender e } \\
\text { aprimorar sua prática. }\end{array}$ & $\begin{array}{c}\text { Imagem majoritária = aluno pouco ágil, } \\
\text { limitado, deficiente; }\end{array}$ & $\begin{array}{c}\text { Última esperança, redentora, que salva e } \\
\text { liberta a humanidade de uma educação } \\
\text { discriminatória e segregacionista. }\end{array}$ \\
& capaz de aprender.
\end{tabular}

Quadro 1: Imagens construídas antes do curso

\footnotetext{
${ }^{5}$ Lembramos que os dados são compostos por dois questionários, um aplicado antes do curso e outro após, além de trechos de discussões estabelecidas no AVA ou de atividades propostas pelos professores.

${ }^{6}$ Nesta pesquisa, os sujeitos serão indicados pela letra S e um número correspondente.
} 
No decorrer do curso, percebemos alterações nas imagens de si e do surdo. De um discurso inicial de impotência e de angústia, passa-se para um discurso de reflexão, de busca de caminhos e práticas alternativas, demonstrando uma compreensão segura do surdo como sujeito sócio-histórico, o que pode interferir no modo de se ensinar português como L2 em sala de aula inclusiva.

Em relação à formação continuada de professores, a imagem positiva é validada e fortificada. Vejamos alguns discursos: Saliento que após essa leitura proposta, revejo meus conceitos, e digo que não só o professor de português, mas todos os servidores sem nenhuma exceção deveriam estudar e serem proficientes em LIBRAS para verdadeiramente efetivar a interação e aí sim ter uma escola inclusiva [...] Realmente esse curso superou todas as minhas expectativas. [...] Garanto que alcancei meus objetivos. Espero em breve outro curso, não posso mais parar!(S6).

De maneira geral, é possível sintetizar as imagens projetadas no decorrer do curso através do quadro a seguir:

\begin{tabular}{c|c|c} 
Imagem de si $($ ethos $)$ & Imagem do surdo & Imagem da formação de professores \\
\hline $\begin{array}{c}\text { Encantado com o saber e com as novas } \\
\text { descobertas, mais confiante e menos }\end{array}$ & $\begin{array}{c}\text { Imagem majoritária = sujeitos político- } \\
\text { culturais de direito, com língua, história, } \\
\text { romântico, capaz de analisar criticamente } \\
\text { o contexto educativo em que está inserido } \\
\text { e reivindicar mudanças. }\end{array}$ & $\begin{array}{c}\text { Muito importante para a prática } \\
\text { Imagem minoritária = sujeito limitado. }\end{array}$ \\
& Quadro 2: Imagens construídas apesar de se reconhecer os \\
seus limites.
\end{tabular}

Ao o término do curso, o surdo passou a ser visto como sujeito sociocultural integrante de uma minoria linguística e não mais como um "deficiente", e o professor-cursista agora se percebe mais consciente e confiante em si mesmo e em sua prática, de modo geral. $\mathrm{O}$ ethos de docente angustiado é anulado, o professor-cursista se mostra entusiasmado com os conhecimentos adquiridos (ethos de docente encantado com o saber), como se verifica nos fragmentos a seguir: É fato que o aluno surdo precisa de uma metodologia de ensino própria, com sala de aula adequada, onde predomine o visual. E que fique claro que o aluno surdo tem as mesmas possibilidades de desenvolvimento que a pessoa ouvinte. [...] Agora com o conhecimento da interlíngua, acho que consigo identificar alguns aspectos na escrita dos meus alunos surdos [...] (S3); Como já mencionei anteriormente, os meus conhecimentos a respeito de ensinar o português como L2 foram enriquecidos e sinto-me mais preparada para trabalhar com os meus alunos em 2015 (S1).

\begin{tabular}{c|c|c} 
Imagem de si (ethos) & Imagem do surdo & Imagem da formação de professores \\
\hline $\begin{array}{c}\text { Confiante, reivindicador, capaz de } \\
\text { buscar novos conhecimento para } \\
\text { aprimorar ainda mais a sua prática. }\end{array}$ & $\begin{array}{c}\text { Sujeitos político-culturais de direito, com } \\
\text { língua, história, identidades e cultura } \\
\text { diferenciadas. }\end{array}$ & $\begin{array}{c}\text { Importante para rever conceitos e práticas } \\
\text { inadequadas e promover a reflexão e } \\
\text { implementação de mudanças. }\end{array}$ \\
\end{tabular}

Quadro 3: Imagens construídas após o curso

Ao finalizar as análises das imagens construídas pelos professores antes, durante e após o curso ofertado, foi possível apreender, no discurso docente, imagens de si que demonstram claramente uma mudança de perspectiva discursiva, mas não necessariamente uma mudança de prática. De modo geral, as seguintes imagens de si (ethos) puderam ser delineadas:

a) a de um profissional que, devido a leitura e discussão dos conteúdos do curso, elabora reflexões sobre o outro (o aluno surdo, o curso, os fatores externos), em um processo em que critica a situação real de ensino para o surdo (vivenciada na própria sala de aula) $\mathrm{x}$ a situação ideal (analisada no curso), apontando dificuldades, destacando a importância do curso para rever conceitos e práticas inadequadas e oferecer suporte para reflexão e implementação de mudanças, ao mesmo tempo em que

Araújo \& Ribeiro | Formação de professores para o ensino de português como segunda língua para surdos.. 
compreende melhor os impedimentos de naturezas diversas (infraestrutura de escolas, políticas públicas, valorização do profissional);

b) a de um cursista que analisa a si mesmo, refletindo sobre sua prática em sala de aula, discutindo a sua responsabilidade frente ao aluno surdo, e, nesse processo, eleva sua autoestima e se percebe como capaz de buscar conhecimento, aprimorar a sua prática e oferecer educação de qualidade a todos, inclusive ao surdo, em um processo de entendimento da Libras como L1 e do português como L2;

c) a de um educador que revê seu entendimento sobre o surdo e constrói imagens positivas a esse respeito; o surdo passa de aluno excluído para aluno valorizado (pois o professor atesta compreender melhor as dificuldades apresentadas por ele na apropriação da L2), tornando-se, assim, mais consciente do seu papel de professor.

Foi possível observar ainda uma imagem de docente em transformação, pautada no aprimoramento da prática pelo entendimento do que é ensinar português como L2 para surdos, na proposta do(s) letramento(s), do engajamento político-social e da alteridade. Nota-se, assim, o afloramento de um discurso de potência, de saber, de questionamento, de busca do conhecimento, de crítica fundamentada, de valorização do outro, alcançando, dessa forma, os objetivos propostos pelo curso.

Mas se, por um lado, foi possível observar avanços consideráveis na percepção do surdo e do ensino do português como L2, que leva o professor-cursista (ao apropriar-se dos conteúdos e das discussões do curso) a refletir sobre sua prática, procurando aprimorá-la, por outro lado, verifica-se um professor-cursista que deixa transparecer, mesmo que eventualmente, um superficialismo prático que consiste na alteração de apenas alguns aspectos da prática e utilização de novas estratégias de ensino, mas que não nos garante uma mudança profunda. Isso, em parte, já era de se esperar, dado que modificar crenças, valores e concepções há muito enraizadas na identidade e prática do professor requer tempo e condições, muitas vezes, externas ao próprio professor e ao seu fazer pedagógico.

Em relação às imagens que esses professores-cursistas projetam do surdo (antes, durante e após o curso), poucos o percebiam por meio de imagens positivas (aluno singular, capaz de aprender), aceitando a surdez como uma diferença; a maioria projetava nele imagens negativas (aluno pouco ágil, limitado, deficiente), vislumbrando a surdez como limitação, deficiência imposta ao sujeito. Ao longo do curso, as imagens negativas do surdo e da surdez vão sendo, progressivamente, desconstruídas (apesar de ainda percebermos resquícios delas em alguns discursos) e as imagens positivas ganham força e se consolidam através do discurso acadêmico de militância surda.

Os dados revelam como inquestionável o fato de a maioria dos docentes enfrentar muitas dificuldades para ensinar português a alunos surdos, pois sentem-se despreparados para isso, seja por não terem uma língua comum que possibilite a troca de conhecimentos, seja por desconhecerem metodologias pertinentes. Ambas as situações resultam de políticas públicas desvinculadas, que não contemplam o contexto educacional que ora se apresenta e, consequentemente, não atendem às necessidades formativas de docentes e surdos. Tais situações resultam ainda da configuração da inclusão educacional para surdos no Brasil, pois inúmeros pesquisadores vêm discutindo que o melhor lugar para se educar surdos são as chamadas escolas/classes bilíngues para surdos, onde currículos, conteúdos e processos são construídos em Língua de Sinais (FERNANDES, 2003; SKLIAR, 1999; SOUZA, GÓES, 1999).

Em se tratando dos possíveis aprimoramentos e/ou transformações na prática docente, constatou-se a importância da formação continuada, mas também os limites da mesma, como apontamos desde o início da pesquisa. Os professores reconhecem que, embora a formação seja primordial, há questões que a ultrapassam, já que, de modo geral, o contexto apresentado na escola inclusiva não favorece o ensino de português como segunda língua para o aluno surdo, uma vez que o docente precisa se dividir entre uma maioria ouvinte e uma minoria surda, fazendo uso de línguas e metodologias diferenciadas. Como consequência, o que se vê, muitas vezes, é uma "inclusão excludente", na qual o surdo precisa se adequar às imposições de um currículo ouvintista - questão que, para ser resolvida, extrapola os limites da formação.

Assim, mesmo tendo acesso a uma formação de qualidade, o docente ainda irá se deparar com questões bastante complexas, como a falta de currículo adaptado, classes mistas, possível ausência de intérprete em sala, necessidade de se usar duas metodologias ao mesmo tempo, falta de materiais didáticos específicos, dentre outras. 
Além disso, os dados da pesquisa nos conduzem a perceber a complexidade do processo de mudança da prática docente, demonstrando que os conhecimentos construídos e/ou apropriados pelos professores-cursistas, nas diferentes atividades das quais participaram, contribuíram significativamente para uma mudança de perspectiva, mas não garantem mudanças efetivas em sua prática pedagógica.

Uma das muitas razões para que isso ocorra consiste na influência das ideologias e representações sociais do grupo a que o docente pertence, fazendo com que os conhecimentos a que foram expostos ganhem sentido ou não na prática cotidiana. Isso nos leva a pensar que a formação precisa concorrer com os demais grupos sociais com os quais os sujeitos interagem, ou melhor, para ser eficiente, a formação precisa ter continuidade e lastro, perdendo o caráter imediatista ou eventual.

\section{CONSIDERAÇÕES FINAIS}

A presente pesquisa ofereceu um curso de formação continuada sobre o ensino de português para surdos, a fim de observar as imagens que os professores fazem de si, dos surdos e do próprio evento de formação, antes, durante e após o seu término. Com isso, objetivou-se refletir sobre os limites e as contribuições da formação continuada para o ensino de português para surdos.

A análise dos dados evidenciou que um interessante jogo de imagens foi construído ao longo do curso, de modo que tanto as imagens de si (dos cursistas) quanto dos surdos e da própria formação foram paulatinamente modificadas por meio das leituras realizadas e interações estabelecidas.

Em se tratando dos possíveis aprimoramentos e/ou das transformações na prática docente, constatou-se a importância da formação continuada, mas também os limites dela, como apontamos desde o início do estudo, já que o contexto apresentado na escola inclusiva não favorece o ensino de português como L2 para o aluno surdo, uma vez que o docente precisa se dividir entre uma maioria ouvinte e uma minoria surda, fazendo uso de línguas e estratégias diferentes. Como consequência, o que se vê é uma "inclusão excludente", na qual o surdo precisa se adequar às imposições de um currículo ouvintista - o que extrapola os limites da formação.

Assim, mesmo tendo acesso a uma formação de qualidade, o docente ainda irá se deparar com problemas talvez intransponíveis, como a falta de currículo adaptado, classes mistas, eventual ausência de intérprete em sala, necessidade de se utilizar de estratégias de ensino específicas aos surdos numa sala composta por maioria ouvinte, falta de materiais didáticos apropriados, dentre outros.

Logo, os dados da pesquisa nos conduzem a perceber a complexidade do processo de mudança da prática docente, por meio da formação, demonstrando que os conhecimentos construídos e/ou apropriados pelos professores-cursistas, nas diferentes atividades das quais participaram, contribuíram significativamente para uma mudança de perspectiva, embora não se possa prever o desdobramento disso na prática pedagógica, dada a complexidade do processo de inclusão de alunos surdos. Soma-se a isso a influência das ideologias e representações sociais do grupo a que o docente pertence, pois elas determinarão se os conhecimentos a que foram expostos serão ou não aceitos, efetivamente, pelos sujeitos.

Por fim, embora haja limites claros para a contribuição da formação de professores para a temática em questão, há também indícios de benefícios inquestionáveis. Entre outras coisas, a formação funciona como um importante instrumento de desconstrução de estigmas e lugares comuns relacionados aos surdos, sua língua e aos processos de ensino-aprendizagem, o que leva à reflexão da própria prática e ao empoderamento do professor. 


\section{REFERÊNCIAS}

ARAÚJO, L. C. Limites e contribuições da formação de professores para o ensino de português como segunda língua para surdos. 2015. 184 f. Dissertação (Mestrado em Letras). - Faculdade de Letras. Universidade Estadual de Montes Claros, Montes Claros, 2015. Disponível em: <http://www.cch.unimontes.br/profletras/images/dissertacoes/DISSERTA $\quad \%$ C3\%87\%C3\%83O__Luciana_Cardoso_de_Ara\%C3\%BAjo.pdf>. Acesso em: 5 fev. 2018.

BRASIL. Ministério da Educação. Lei n. de Diretrizes e Bases da Educação Nacional, LDB 9.394, de 20 de dezembro de 1996. Estabelece as diretrizes e bases da educação nacional. Diário Oficial da União, 23 dez. 1996. Disponível em: <http://www.planalto.gov.br/ccivil_03/leis/19394.htm>. Acesso em: 23 maio 2013.

BRASIL. Decreto 5.626, de 22 de dezembro de 2005. Regulamenta a Lei n.o 10.436, de 24 de abril de 2002, que dispõe sobre a Língua Brasileira de Sinais - Libras, e o art. 18 da Lei n. 10.098, de 19 de dezembro de 2000. In: Diário Oficial da União de 23 de dez. de 2005, Brasília, p. 28, 23 dez. 2005. Disponível em: <http://www.planalto.gov.br/ccivil_03/_ato2004-2006/2005/decreto/d5626.htm>. Acesso em: 05 nov. 2013.

BRASIL. Ministério da Educação. Referenciais para formação de professores. Secretaria de Educação Fundamental. Brasília, 1998. Disponível em: <http://portal.mec.gov.br/seb/arquivos/pdf/Livro.pdf>. Acesso em: 05 nov. 2013.

FERNANDES, Sueli de Fátima. Educação bilíngue para surdos: identidades, diferenças, contradições e mistérios. $2003.213 \mathrm{f}$. Tese (Doutorado em Letras) - Setor de Ciências Humanas, Letras e Artes, Universidade Federal do Paraná, Curitiba, 2003. Disponível em: $<$ https://acervodigital.ufpr.br/bitstream/handle/1884/24287/T\%20-

\%20FERNANDES,\%20SUELI\%20DE\%20FATIMA\%20.pdf?sequence=1>. Acesso em: 23 jan. 2014.

FIORIN, J. L. Linguagem e ideologia. São Paulo: Ática, 1988.

GATTI, B. A. Análise das políticas públicas para formação continuada no Brasil, na última década. Revista Brasileira de Educação,. v. 13, n. 37, jan./abr. 2008. Disponível em: <http://www.scielo.br/pdf/rbedu/v13n37/06.pdf>. Acesso em: 12 jan. 2014.

LORENZETTI, M. L. A inclusão do aluno surdo no ensino regular: a voz das professoras. Revista Espaço, São Paulo, 2006. Disponível em: <http://www.ines.org.br/paginas/revista/espaco18/Atualidade01.pdf >. Acesso em: 13 maio 2014.

MAINGUENEAU, D. A propósito do ethos. In: MOTTA, A. R. ; SALGADO, L. (Org.). Ethos discursivo. São Paulo: Contexto, 2014. p. 11-29.

MAINGUENEAU, D. Cenas da enunciação. [Org. Cecília Souza-e-Silva e Sírio Possenti]. Tradução de Cecília Souza-e-Silva e Sírio Possenti. São Paulo: Parábola, 2008.

PÊCHEUX, M. Semântica e discurso: uma crítica à afirmação do óbvio. Campinas: Editora da Unicamp, 1988.

QUADROS, R. M. de. O Bi do bilinguismo na educação de surdos. In: FERNANDES, E. (Org.). Surdez e bilinguismo. Porto Alegre, RS: Editora Mediação, 2005. p. 26-36.

RIBEIRO, M. C. M. de A. A escrita de si: discursos sobre o ser surdo e a surdez. 2008. 178 f. Dissertação (Mestrado em Estudos Linguísticos) - Faculdade de Letras, Universidade Federal de Minas Gerais, Belo Horizonte, 2008. Disponível em: <http://www.bibliotecadigital.ufmg.br/dspace/bitstream/handle/1843/ALDR-7LXNMP/1270m.pdf?sequence=1>. Acesso em: 09 jan. 2014. 
RIBEIRO, M. C. M. de A. O discurso acadêmico-científico produzido por surdos: entre o fazer acadêmico e o fazer militante. 2012.263 f. Tese (Doutorado em Estudos Linguísticos) - Faculdade de Letras, Universidade Federal de Minas Gerais, Belo Horizonte, 2012. Disponível em: <http://www.bibliotecadigital.ufmg.br/dspace/handle/1843/LETR-96LNYY>. Acesso em: 09 jan. 2014.

RODRIGUES, D. Dez ideias (mal) feitas sobre a Educação Inclusiva. In: RODRIGUES, D. (Org.). Inclusão e educação: doze olhares sobre a educação inclusiva. São Paulo: Summus, 2006. p. 299-318.

SKLIAR, C. (Org.). Educação e exclusão: abordagens sócio-antropológicas em educação especial. Porto Alegre: Ed. Mediação, 1997.

SOUZA, R. M. de; GÓES, M. C. R. O ensino para surdos na escola inclusiva: considerações sobre o excludente contexto da inclusão. In: SKLIAR, C. (Org.). Atualidade da Educação Bilíngue para Surdos: processos e projetos pedagógicos. Porto Alegre: Mediação, 2013. p. 163-188.

UNESCO. Declaração de Salamanca. Sobre os princípios, políticas e práticas na área das necessidades educativas especiais. Salamanca, 1994. Disponível em: < <http://redeinclusao.web.ua.pt/files/fl_9.pdf > Acesso em: jan. 2014.

UNESCO. Declaração Mundial de Educação para Todos. Jomtien, 1990. Disponível em: $<$ https://www.unicef.org/brazil/pt/resources_10230>. Acesso em: 13 jan. 2017. 